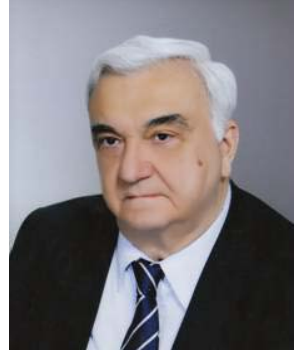

\title{
PUBLISHING INTEGRITY AND GOOD PRACTICES IN EDITING IN BIOMEDICINE
}

\author{
Momir Polenakovic ${ }^{1 *}$, Zoran Gucev²
}

\author{
${ }^{1}$ The Macedonian Academy of Sciences and Arts, Skopje, R. Macedonia \\ ${ }^{2}$ Paediatric Clinic, Medical Faculty Skopje, R. Macedonia
}

Corresponding Author: Momir Polenakovic, Macedonian Academy of Sciences and Arts, Bul. Krste Misirkov br. 2 1000 Skopje, R. Macedonia; Tel: + 389 (0)2 32354 00; Fax: + 389 (0)2 32355 00; E-mail: maknefpo@t-home.mk

*To whom all correspondence should be addressed

\begin{abstract}
The Macedonian Academy of Sciences and Arts (MASA), held a scientific workshop for journal editors in biomedicine: "Publishing integrity and good practices in editing in biomedicine" on April 25, 2014 in MASA, Skopje. The meeting looked into old problems and new situations in editing and publishing, with emphasis on the situation in developing countries.

This global knowledge-based society is founded on the results obtained from scientific research. The data from basic research in developed countries contribute in a quite substantial manner to the newly added economic value. One of the main reasons for underdevelopment in South Eastern Europe (SEE) is certainly a low or non-existent contribution of scientific research in the newly added economic value. This has largely to do with the perception of the political elites which simply lack the insight on the crucial importance of science in development. In the long term this leads to societies in which there are distortions in the understanding of the most basic values.

Academic publishing has experienced tremendous growth: so far there are at least 50 million scientific articles. Interestingly, publishing in developing countries has experienced a rate of growth higher than in developed countries. However, this is not the case with the Balkan countries.

The meeting looked at some old and some newly emerging problems in editing and publishing.

First, the high cost for universities and researchers to purchase journals adversely affects both publishing and editing. In developing countries the high cost of purchasing scientific literature is an almost insurmountable problem in spite of the fact that some publishing companies offer discounted fees. Open access journals in South Eastern European (SEE) countries are hardly achievable as this also incurs costs that have to be covered in some way or other.

The peer review process has the fundamental difficulty that reviewers are in the situation of a Procrustean bed, tending to accept reports which support the reviewer's concepts of thinking and, like Procrustes, cutting everything else out. Authorship is often a contentious issue, as undeserved authors appear on the list of authors.

Some principles are now a norm in academic publishing. This applies to the declaration of a conflict of interest, the consent of the patient and the approval of the Ethical Board of the institution.

This global informational technological revolution has, unfortunately, led to largely widespread and increasingly sophisticated deviations: plagiarism, data fabrication and data falsification as forms of scientific misconduct. Those events are now more widespread than in the past. Luckily new tools to track them are much better than previously.

The race for perfect publishing integrity and for the best good practices in editing in biomedicine is on. New and old challenges will be met. The benevolent and caring society, educated professionals and an enlightened public remain essential preconditions. The wealth of nations depends on R\&D and consequently on academic publishing.
\end{abstract}


Key words: biomedicine, editing, publishing integrity.

\section{Introduction}

Humanity, from the very beginning, and all humans in particular, have wanted to leave a permanent record of their existence, problems, and achievements. The phenomenal paintings in the Spanish Cave at Altamira, the complex and beautiful scriptures of ancient times were used to record culture, ideas and development for the generations to come.

There have been just two publishing revolutions: Gutenberg's printing press and the world wide web (www). Today, there is the internet which forms a giant connecting web present in the most remote corners of the world and we can expect an explosion of human creation. This global informational technological revolution, has unfortunately led to largely widespread and increasingly sophisticated deviations: plagiarism, data fabrication and data falsification as forms of scientific misconduct.

The Macedonian Academy of Sciences and Arts (MASA), held a scientific workshop for journal editors in biomedicine: "Publishing integrity and good practices in editing in biomedicine" on April 25, 2014 in MASA, Skopje. The meeting looked into old problems and new situations in editing and publishing, with emphasis on the situation in the developing countries. Prof. Marusic (Croatia) and Prof. Wager (Germany) made an interesting contribution to the topic of medical publishing in the modern world. Acad. Polenakovic, Professors Doncho Donev, Mirko Spiroski, Zoran Gucev, Dijana Plasevska-Karanfilska, Zoran Zdravkovski, Goce Spasovski and Azis Pollozhani each gave their views on editing and publishing difficulties in today's webbased world.

During the meeting, the Macedonian Association of Medical Editors was established.

\section{The global knowledge-based society and scientific research}

This global knowledge-based society is founded on the results obtained from scientific research. The data from basic research in developed countries contributes in a quite substantial manner to the newly added economic value. One of the main reasons for underdevelopment in South Eastern Europe (SEE) is certainly its low or non-existent contribution of scientific research in the newly added economic value. This has largely to do with the perception of the political elites which simply lack insight into the crucial importance of science in development. In the long term this leads to societies in which there are distortions in the understanding of the very basic values.

In the developed world the emphasis of the state is on research and development (R\&D). The money invested in $R \& D$ as a percentage of their GDP is directly proportional to the number of scientists, and the number of patents registered in those countries. This in its turn gives a giant boost to their economies and the well-being of their populations.

In addition, those countries have the luxury of a long tradition of private donations. Recently Michael Bloomberg donated to his alma mater John Hopkins 350 million dollars, raising his total donation to John Hopkins to 1.1 billion dollars [1].

Academic publishing disseminates academic research in the form of academic articles in specialised journals and also includes publishing books or scientific theses. The first journal that appeared as scientific was the Journal des sçavans (Journal des savants) which appeared on $5^{\text {th }}$ January 1665 [2].

The USA and the EU are leading in terms of the volume of published articles and in the "top one per cent of highly cited scientific papers". In 2004, the EU share was 39.3 and 37.5 respectively, while the USA share was 49.4 per cent and 62.8 per cent [3].

Academic publishing has experienced tremendous growth: so far there are at least 50 million scientific articles [4]. Interestingly, publishing in developing countries has experienced a rate of growth higher than those in developed countries. The Middle East, Asia, Iran, the Republic of Korea, Turkey, Cyprus, China, and Oman [5] all show stunning growth in the volume of published scientific articles. It is of note that China, India, Brazil, Iran, and South Africa cover $97.5 \%$ of the most cited scientific articles, while the remaining 162 countries contribute less than $2.5 \%$ [3]. All the Balkan countries are in the latter group. 


\section{On old problems and new situations in academic publishing}

The meeting looked at some old and some newly emerging problems in editing and publishing.

First, the high cost for universities and researchers to purchase journals adversely affects both publishing and editing. Strikingly only three companies (Reed Elsevier, Springer \& Business Media, and John Wiley \& Sons) account for $42 \%$ of articles. Their margins of profit are extremely high and generate billions of dollars in revenue [6]. In developing countries the high cost of purchasing scientific literature is an almost insurmountable problem in spite of the fact that some publishing companies offer discounted fees. Therefore, some fine researchers are deprived of the opportunity to share their contribution with the global world of knowledge. This is an urgently pending matter for all the SEE countries.

Publishing integrity in SEE is under the influence of the high costs of publishing too. As publishing is expensive, sponsorship and advertisement are the main sources of financing. In the small communities of SEE this adversely affects the quality of published research as sponsors sometimes have an unwanted leverage on publishing policies.

Open access journals in South Eastern European (SEE) countries are hardly achievable as this also incurs costs that have to be covered in some way. For the SEE it is almost not achievable to follow the example of some open access journals, like the Public Library of Science (PLOS) and BioMed Central (BMC), which offer free access to academic articles to paying customers. Researchers often themselves pay the article-processing charge (APC). On the other hand some bodies, e.g. British research councils, require that the works they pay for are open access. The prestigious Nature Publishing Group (NPG) will publish a journal free for readers. It has to be stressed that the rejection rate for the high-end paid-for journals is often more than $90 \%$. Open access journals might therefore lower the threshold of quality by publishing anything. Grant-awarding bodies on the other hand tend to grant awards to those who publish in the top journals which are not open access [7]. In addition, most open access journals offer free access for authors in underdeveloped countries.

The peer review process is the cornerstone of academic publishing. The quality of the scholars' work is assessed by experts in the same scientific field. This process has significant downsides. The fundamental difficulty is that reviewers are in the situation of a Procrustean bed tending to accept reports which support the reviewer's concepts of thinking and, like Procrustes, cutting everything else out. There is a long and rather notorious list of important and even revolutionary scientific articles rejectted by highly prestigious journals. For example, in 1796 Edward Jenner's report of the first vaccination against smallpox was rejected by the Philosophical Transactions [8].

Fairness and objectivity are especially difficult to attain in small communities in developing countries where reviews have a tendency to be either uncritically positive or unscrupulously negative.

In general the authorship is based on the intellectual contributions that led to the completion of the research. This has become a primary tool upon which employment, promotion, and tenure of researchers are based. This leads to a tremendous pressure on researchers and academics to publish. Publish or perish and fund or famish are the leading mottoes in the research and academic community of today. Some authors buckle and the list of affairs of research misconduct are growing by the hour. The result is ruined careers, court cases. Recently the stem cell scientist from the Japan's RIKEN Centre For Developmental Biology in Kobe Yoshiki Sasai committed suicide (hanging himself from a stairway railing in the RIKEN complex), after being involved in the scandal on a stem cell paper published in Nature on $29^{\text {th }}$ January and retracted on $2^{\text {nd }}$ July [9].

Many journals have limited their authorship to those who have contributed substantially to the work $[10,11]$. However, this is often not respected. More than $10 \%$ of authors claimed to have inappropriately assigned authorship [12, 13]. In our experience, in SEE this would be the lower limit of undeserved authorship. 
Therefore, some journals have the policy that each manuscript includes a statement of responsibility which specifies the contribution of each author. In some articles there are several hundred authors (14), reflecting the contribution of many professionals in recruiting the patients for a particular study. Therefore, some journals have changed the notion of author to that of contributor.

In ghost authorship an individual makes a substantial contribution to the creation of the article, but is not in the list of authors. This gained notoriety in the industry-initiated randomized trials [15].

The order on the list of authors is often controversial and can result in scientific misconduct. It often leads to much friction and undeserved authorship. The principle of "credit where credit is due" should also be applied when considering the order in the list of authors [16].

Anonymous authorship has been used by authors to protect themselves when presenting controversial results or theories. In addition, those working in corporate and military organizations are often restricted from publishing as their results are considered secret. A very famous example is the widely used student $t$ test. Namely, William Gosset published his work as "Student" due to his employment at the Guinness brewery.

Some principles are now a norm in academic publishing. This applies to the declaration of the conflict of interest, the consent of the patient and the approval of the Ethical Board of the institution.

\section{Publishing integrity and good practices in editing in biomedicine}

This global informational technological revolution has, unfortunately, led to largely widespread and increasingly sophisticated deviateons: plagiarism, data fabrication and data falsification as forms of scientific misconduct. Those events are now more widespread than in the past. Luckily new tools to track them are much better than previously.

New tools to detect scientific misconduct are emerging (www.science-fraud), making detection of scientific misconduct easier. The site www.retractionwatch is also extremely instructive.

Plagiarism is frequent in biomedicine, but when discovered among representatives of the people its effects are widely bombastic for the general public. Annette Schavan, a former German Minister for Science and Education (!) lost the ministerial position on 7th April 2014 when investigation on alleged plagiarism of her doctorate began to be investigated [17]. Heinrich Heine University revoked her title because she had plagiarized other works with intent to deceive. She shared the destiny of Theodor von Gutenberg, the former German Minister of Defense (resignation March 2011).

Great care is taken to punish the fraudsters. Diederik Stappel's professional reputetion went from hero to zero. The report publicshed by Tilburg University on October 31st, 2011, found the excessive and long scope of the misconduct and scientific fraud carried out by Diederik Stappel [18].

The number of retracted papers is growing. Notorious recent examples are the articles on stem cells by the now infamous Korean researcher Woo-Suk Hwang. Science editorially retracted the two papers by Hwang et al. on 12th January 2006 [19-22]. Investigation by the journal and Woo-Suk Hwang's University found the data to be fabricated and falsified [23].

As with any crime and misconduct, the race between dishonesty and justice is long and complex. Dishonesty often goes one step faster than justice. Recently, Science has exposed a black market in China in the commodity of articles published in journals with impact factor (IF) [24]. Regular advertisement was selling authorship in renowned journals. In a way, one could buy a scientific career. The price: just $14000 \$$ for the "big" journals, or less for journals with lower IF.

The race for perfect publishing integrity and for the best good practices in editing in biomedicine is on. New and old challenges will be met. A benevolent and caring society, educated professionals and an enlightened public remain essential preconditions. The wealth of nations [25] depends on R\&D and consequently on academic publishing. 


\section{REFERENCES}

1. Barbaro M. \$1.1 Billion in Thanks From Bloomberg to Johns Hopkins. New York Times. 2013; January 27, page A1.

2. Philosophical Transactions of the Royal Society Vol. 1, Issue 1, is dated March 6, 1665. In: Wikipedia. Academic publishing. Retreived. 2014-08-07.

3. Dickson D. China, Brazil and India lead southern science output. Sci. Dev. Net. 2004; Retrieved 2012-08-07.

4. Jinha AE. Article 50 million: An estimate of the number of scholarly articles in existence. Learned Publishing. 2010; 23 (3): 258-263.

5. MacKenzie D. Iran showing fastest scientific growth of any country. Science in Society. New Scientist (online magazine) 2010; Retrieved. 2014-08-01.

6. McGuigan GS, Russell RD. The Business of Academic Publishing: A Strategic Analysis of the Academic Journal Publishing Industry and its Impact on the Future of Scholarly Publishing. E-JASL: The Electronic Journal of Academic and Special Librarianship. ICAAP; 2008.

7. Scientific publishing, grand openings. The Economist. September 27-October 3, 76.

8. Kronick DA. Peer review in 18th-century scientific journalism. JAMA. 1990; 263: 10, 1321-1322.

9. Normile D. Cell biologist commits suicide. Science. 2014; 606.

10. Dickson JG, Conner RN, Adair KT. Guidelines for Authorship of Scientific Articles. Wildl Soc Bull. 1978; 6 (4): 260-261.

11. Rennie D, Yank V, Emanuel L. When authorship fails. A proposal to make contributors accountable. JAMA. 1997; 278(7): 579.

12. Ilakovac V, Fister K, Marusic M, Marusic A. Reliability of disclosure forms of authors' contributions. Canadian Medical Association Journal. 2007; 176 (1): 41-46.

13. Martinson BC, Anderson MS, De Vries R. Scientists behaving badly. Nature. 2005; 435 (7043): 737.

14. Pagani O, et all. TEXT and SOFT Investigators; International Breast Cancer Study Group. Adjuvant exemestane with ovarian suppression in premenopausal breast cancer. - N Engl J Med. 2014; 10; 371(2): 107-18. Collaborators (609).

15. Gøtzsche PC, Hróbjartsson A, Johansen HK, Haahr MT, Altman DG, Chan AW. Ghost authorship in industry-initiated randomised trials. PLoS Medicine. 2007; 4 (1): 47-52.

16. Helen Pearson. Credit where credit's due. Nature. 2006; 440 (7084): 591-708.

17. Nina Werkhäuser. A chronology of the Schavan plagiarism affair. Deutche Welle. 10.02.2013.

18. Tilburg University. Interim report regarding the breach of scientific integrity committed by prof. D.A. Stapel. Tilburg University. 2011; 1-21.

19. Hwang WS, Ryu YJ, Park JH, Park ES, Lee EG, Koo JM, et al. Evidence of a Pluripotent Human Embry- onic Stem Cell Line Derived from a Cloned Blastocyst. Science. 2004; 303: 1669-1674.

20. Hwang WS, et all. Patient-Specific Embryonic Stem Cells Derived from Human SCNT Blastocysts. Science. 2005; 308: 1777-1783.

21. Kennedy D. Editorial Retraction of Hwang et al. Papers, Science. 2006; 311: 335.

22. Kennedy D. Editorial: Responding to Fraud. Science 1 December 2006; 314: 1353.

23. Wohn Y. Seoul National University Dismisses Hwang. Science. 2006; 311: 1695.

24. Mara Hvistendahl. China's Publication Bazaar. Science. 2013; 342, 1035-1039.

25. Smith A. The Wealth of Nations. 1976, edited by R. H. Campbell and A. S. Skinner, The Glasgow edition of the Works and Correspondence of Adam Smith.

Резиме

\section{ИЗДАВАЧКИ ИНТЕГРИТЕТ И ДОБРИ ПРАКТИКИ ВО УРЕДУВАЫЕТО ВО БИОМЕДИЦИНАТА}

\author{
Момир Поленаковиќ ${ }^{1 *}$, Зоран Гучев ${ }^{2}$ \\ ${ }^{1}$ Македонска академија на науките \\ и уметностите, Скопје, Р. Македонија \\ ${ }^{2}$ Клиника за детски болести, Медицински \\ факултет, Универзитет „Св. Кирил и Методиј“, \\ Скопје, Р. Македонија
}

На 25 април 2014 година во Македонската академија на науките и уметностите (МАНУ) се одржа научен состанок за уредниците на списанијата од биомедицината. Темата на научниот состанок беше: „Издавачки интегритет и добри практики во уредувањето во биомедицината“. На средбата се разгледуваа старите проблеми и новите ситуации во уредувањето и издавањето, со акцент на состојбата во земјите во развој.

Денешното глобално општество, базирано на знаење, се заснова на резултатите добиени од научни истражувања. Резултатите добиени од фундаментални научни истражувања во развиените земји во голема мера ја чинат новододадената економски вредност на општествата во целина (knowledge based or innovation driven society). Една од главните причини за неразвиеноста во Југоисточна Европа (ЈИЕ), секако, е малиот или непостоечки придонес на научното истражување во економијата на земјите. Овие економии остануваат засновани на производство на суровини или полуфабрикати, што ги прави cè посиромашни. Оваа ситуација во голема мера произлегува од перцепцијата на политичките ели- 
ти, кои немаат увид за клучното значење на науката во економскиот развиток на општеството. Подолг временски период оваа ситуација води до креирање општества со нарушено разбирање на основните вредности на човековото битие.

Академското издаваштво доживеа огромен пораст: досега има најмалку 50 милиони публицирани научни статии. Интересно, издаваштвото во земјите во развој доживеа стапка на раст повисока отколку во развиените земји. За жал, балканските земји не доживеаја таков пораст.

Кои се старите и новонастанати проблеми во уредувањето и издавањето?

Прво, високата цена на претплата за научни списанија е неподнослива и за универзитетите и за истражувачите и покрај фактот што некои издавачки компании нудат намалени цени. Публицирањето списанија со отворен пристап (open source) во Југоисточна Европа (JИЕ), исто така, подразбира соочување со фундаменталната вистина дека и овој тип издавање е поврзан со трошоци што мора да бидат покриени од некој извор.

Процесот на рецензија има основна тешкотија што рецензенти се во ситуација на Прокрустов кревет, со тенденција да се прифаќаат трудови што го поддржуваат концептот на размислување на рецензентот кој како Прокруст отсечува сѐ што не се вклопува во неговата шема на разбирање. Авторството често е спорно прашање, бидејќи автори што немаат заслуга често се наоѓаат на списокот на автори.
За среќа, некои принципи сега се норма во академското издаваштво. Ова се однесува на задолжителната изјавата за судир на интереси, согласноста на пациентот и одобрување на Етичкиот одбор на институцијата, при што сите се потребни за трудот да биде прифатен за печатење.

Оваа глобална информатичка технолошка револуција, за жал, доведе и до широкораспространети и сѐ пософистицирани девијации: плагијати, измислување и фалсификување научни податоци. Треба да се истакне дека новите средства за нивно откривање се многу поусовршени и водат до рано откривање на овие девијации кои потоа се предмет на легални процеси со тешки последици за прекршителите.

Трката за совршен издавачки интегритет и за најдобрите практики во уредувањето во биомедицината е во тек. И новите и старите предизвици ке добијат или веќе добиваат соодветни одговори. За напредок на издаваштвото, но и за целото општество, потребни се добронамерно и грижливо управување со општеството, одлично образовани експерти и просветена јавност. Сите овие се суштински предуслови за напредно и богато општество. „Богатството на нациите“ зависи од истражувањето и развојот и, следствено, од академското издаваштво.

Клучни зборови: биомедицина, уредување, издавачки интегритет. 